\title{
THE INFLUENCE OF PICTURE COLORING ON FINE MOTOR DEVELOPMENT IN CHILDREN AGED 4-5 YEARS
}

\author{
Nining Fitrianingsih ${ }^{a *}$, Noor Siti Noviani Indah Sari ${ }^{a)}$ \\ ${ }^{a)}$ Sekolah Tinggi Ilmu Kesehatan Wijaya Husada, Bogor, Indonesia \\ ${ }^{*}$ e-mail korespondensi : nienk1406@yahoo.com
}

Article history: received 28 December 2018; revised 17 January 2019; accepted 25 January 2019

\begin{abstract}
Abstrak. According to the World Health Organization (WHO) reports that 2-25\% of preschool age children suffer from minor brain dysfunction, including impaired fine motor development, in Indonesia around $16 \%$ of children experience impaired fine motor development. Fine motor development involves certain body parts performed by small muscles. How to stimulate fine motor skills in children has a very large function, namely to increase the movement of fine activities such as writing, drawing, and typing. The impact that will occur if the child has a disruption in fine motor development that can cause cerebral palcy. To determine the effect of coloring pictures on fine motor development in children aged 4-5 years. This type of research is pre-experimental and conducted in Al-Munawar Kindergarten, Nanggung District with respondents, namely children aged 4-5 years using Total Sampling. The instrument used was an observation sheet. Knowing univariate analysis before given coloring treatment $50 \%$ of children in the category of undeveloped and after being given coloring treatment $50 \%$ of children in the development category as expected. Bivariate analysis using the normality test using Shapiro Wilk with the results of $0,000<0.05$ means that the data is not normally distributed, after that to test the hypothesis using Willcoxon with a $\mathrm{P}$ value of $0,000<0.05$, it means that Ha is accepted. Knowing fine motor development of the respondents $50 \%$ of respondents fall into the category of undeveloped with a mean value of 1.87 and a standard deviation of 0.937 . Knowing fine motor development of $50 \%$ of respondents included in the category of developing according to expectations with a mean value of 2.90 and a standard deviation of 0.712. The Influence of Coloring Pictures Against Fine Motoric Development in Children Aged 4-5 Years at Al-Munawar Kindergarten, Nanggung District, Bogor Regency.
\end{abstract}

Keywords: Coloring Pictures, Fine Motor Development, Children 4-5 Years

\section{INTRODUCTION}

Children under five as a golden age or "golden age" that is human beings aged 0-6 years (Law no. 20 of 2003), although some experts say children under five are vulnerable children aged 0-8 years. Developments experienced during the golden age are physical, cognitive, linguistic, emotional, adaptive, social, personal, and motoric [1].

In Indonesia the number of children under five years old is 23.7 million or around $10.4 \%$ of the total population of Indonesia [2]. The number of children aged 1-5 years in the West Java area there are 5.6 million children [3] and the number of children aged 4-5 years in Bogor Regency is 113,232 children [2].

In general, growth has certain characteristics, namely changes in body proportions that can be observed in infancy and adulthood, irregular growth rates and are characterized by certain periods of prenatal, infant and adolescence, where rapid growth occurs. World health organitation (WHO) reports that $2-25 \%$ of preschool-aged children suffer from minor brain dysfunction, including impaired fine motor development [4]. Globally reported children who experience disorders in the form of anxiety around 9\%, easy emotions $11-15 \%$, behavior disorders $9-15 \%$ [5].

The number of children under five in Indonesia experienced 0.4 million fine motor and gross motor development disorders or around $16 \%$ [4]. Student prevalence rate (growth inhibition) in toddlers is around
$24.5 \%$. Monitoring of the growth of children under five every month shows that the percentage of toddlers aged 6-59 months who have never been weighed in the last 6 months tends to increase from $25.5 \%$ in $2007,23.8 \%$ in 2010 , to $34.4 \%$ in 2013. Disorders speech and language development is often found in children aged 3-16 years. It is estimated that the incidence rate ranges from $1 \%$ to $32 \%$ in the normal population [2]. The purpose of this study was to determine the effect of coloring pictures on fine motor development in children aged 4-5 years group $\mathrm{A}$ in Al-Munawar Kindergarten, Nanggung District, Bogor Regency.

\section{RESEARCH METHODS}

This study uses the one group pre-test and post test design method by giving a pre-test (initial observation) before giving intervention. After that the intervention is given, then post test (final observation). This research was conducted at Al-Munawar Kindergarten. By taking a total sampling of the population.

The variables of this study consisted of the influence of coloring pictures and fine motor development in children aged 4-5 years. Data processing and data analysis using computer programs. The analysis consisted of univariate and bivariate analysis, where bivariate analysis analyzed the effect of coloring pictures on fine motor development in 
children aged 4-5 years in group A of Al-Munawar Kindergarten.

\section{RESULTS AND DISCUSSION}

This study began by observing the development of fine motor before being given a coloring treatment for 20 minutes, then given a coloring treatment for 50 minutes and one day after that for 20 minutes, observing fine motor development again after being given a coloring treatment for children aged 4-5 years group $\mathrm{A}$ in Al-Munawar Kindergarten

Table 1 Frequency Distribution of fine motor development before giving color coloring treatment

\begin{tabular}{|l|c|c|}
\hline \multicolumn{1}{|c|}{ Category } & Frequency & Percentage (\%) \\
\hline Undeveloped & 15 & 50 \\
\hline Began to develop & 4 & 13,3 \\
\hline $\begin{array}{l}\text { Develop according to } \\
\text { expectations }\end{array}$ & 11 & 36,7 \\
\hline Very well developed & 0 & 0 \\
\hline \multicolumn{1}{|c|}{ Total } & 30 & 100 \\
\hline
\end{tabular}

SPSS 16

Based on the results of table 1 about the frequency distribution of fine motor development before coloring treatment is known from respondents, the majority of respondents ie $50 \%$ of them are included in the undeveloped category.

Table 2 Average values and standard deviations of fine motor development before treatment with coloring pictures

\begin{tabular}{cccc}
\hline Treatment & Frequency & Mean & $\begin{array}{c}\text { Standard } \\
\text { Deviation }\end{array}$ \\
\hline Before Coloring & 30 & 1,87 & 0,937 \\
\hline SPSS 16 & & &
\end{tabular}

Based on table 2 about the average value and standard deviation of fine motor development before being given a coloring treatment, it is known from the respondent that there is a mean value of 1.87 and the standard deviation value is 0.937 .

Based on the results of table 3 the distribution of the frequency of fine motor development after being given a treatment coloring pictures of the respondents after being given a treatment coloring pictures, as many as 50\% of children included in the category of development as expected.
Table 3 Frequency Distribution of fine motor development after coloring treatment

\begin{tabular}{|l|c|c|}
\hline \multicolumn{1}{|c|}{ Category } & Frequency & Percentage (\%) \\
\hline Undeveloped & 0 & 0 \\
\hline Began to develop & 9 & 30 \\
\hline $\begin{array}{l}\text { Develop according to } \\
\text { expectations }\end{array}$ & 15 & 50 \\
\hline Very well developed & 6 & 20 \\
\hline \multicolumn{1}{|c|}{ Total } & 30 & 100 \\
\hline
\end{tabular}

SPSS 16

Table 4 Mean values and standard deviations of fine motor development after treatment with coloring pictures.

\begin{tabular}{cccc}
\hline Treatment & Frequency & Mean & $\begin{array}{c}\text { Standard } \\
\text { Deviation }\end{array}$ \\
\hline After Coloring & 30 & 2,90 & 0,712 \\
\hline
\end{tabular}

SPSS 16

Based on table 4 about the average value and standard deviation of fine motor development after being given treatment coloring pictures of $50 \%$ of respondents there is a mean value of 2.90 and the standard deviation value is 0.712

Table 5 Bivariate analysis of the normality of pretest and posttest data effects of coloring pictures on fine motor development in children aged 4-5 years

\begin{tabular}{lll}
\hline Variable & N & Normality test \\
\hline \multicolumn{2}{l}{ fine motor development } \\
Pre_Coloring & 30 & 0,000 \\
\hline Post_Coloring & 30 & 0,000 \\
\hline
\end{tabular}

Based on the results of table 5 on the bivariate analysis of the normality of pretest and posttest data the influence of coloring pictures on fine motor development in children aged 4-5 years was obtained from the data normality test using Shapiro Wilk before being given a coloring treatment picture is 0,000 and after being given a coloring treatment image is 0,000 . The normality test results above get the value of pre_color $=0,000<0.05$ and post_color $=0,000<0.05$ meaning the data above is not normally distributed.

Table 6 Bivariate analysis of the pretest and posttest homogeneity test the effect of coloring pictures on fine motor development in children aged 4-5 years

\begin{tabular}{|c|c|c|}
\hline Variable & $\mathrm{N}$ & Homogeneity Test \\
\hline \multicolumn{3}{|c|}{ fine motor development } \\
\hline Pre_Coloring & 30 & 0,000 \\
\hline Post_Coloring & 30 & 0,063 \\
\hline
\end{tabular}


Based on the results of table 6 on the bivariate analysis of the pretest and posttest homogeneity test the effect of coloring pictures on fine motor development in children aged 4-5 years was obtained homogeneity test results using the Levene test before being given a coloring treatment picture was 0,000 and after being given a coloring treatment picture was 0.063 . Homogeneity results above get the value of pre_coloring $=0,000<0.05$ and post_coloring $=0.063>0.05$ meaning that before the treatment is given coloring the image above data is not homogeneous and after being given a coloring treatment the data image above is homogeneous.

Table 7 Bivariate analysis of hypothesis testing of pretest and posttest data the effect of coloring pictures on fine motor development in children aged 4-5 years

\begin{tabular}{|c|c|c|c|c|c|c|}
\hline Variable & $\mathrm{N}$ & Means & $\begin{array}{l}\text { Std. } \\
\text { Dev. }\end{array}$ & Min. & Maks. & P Value \\
\hline \multicolumn{7}{|c|}{ fine motor development } \\
\hline $\begin{array}{l}\text { Pre_}_{-} \\
\text {Coloring }\end{array}$ & 30 & 1.87 & 0,937 & 1 & 3 & \multirow[t]{2}{*}{0,000} \\
\hline $\begin{array}{l}\text { Post_ } \\
\text { Coloring }\end{array}$ & 30 & 2.90 & 0,712 & 2 & 4 & \\
\hline
\end{tabular}

Based on the results of table 7 about the bivariate analysis of the pretest and posttest data hypothesis the effect of coloring pictures on fine motor development in children aged 4-5 years was obtained from the hypothesis test data using Will Coxon before and after the treatment of coloring pictures was $0,000(<0,05)$. This means that there is an effect of coloring pictures on fine motor development in children aged 4-5 years, $\mathrm{Ha}$ is accepted

\section{Univariate}

Based on the data obtained from the univariate results, there is a value of the frequency distribution of fine motor development before being given a coloring treatment of the 30 respondents most of which fall into the underdeveloped category of $50 \%$, the mean value is 1.89 and the standard deviation value is 0.937 . While the frequency distribution values after being given treatment coloring pictures of 30 respondents mostly fall into the category of developing according to expectations of $50 \%$, the mean value of 2.90 and the standard deviation value of 0.712. Judging from the values before and after the treatment of animals, there are differences in values that increase. Coloring is a favorite activity for children, especially for children who want to learn to recognize colors. In this activity children are given the freedom to choose colors and combine colors. Coloring is a skill that is loved by children. coloring is also a medium for them to express their imagination and inspiration about everything that has been touched and experienced [6].

This is in accordance with research conducted by Niluh Sri Murdian [7] This study uses data collection techniques, observation and assignments. The results obtained before given the task of coloring pictures of the number of respondents 25 there is a mean value of 1.58 and after given the coloring activity there is a mean value of 2.65 where there are $80 \%$ of children have sufficient fine motor skills, and there are $4 \%$ of children have less fine motor skills

\section{Bivariate}

Based on the data obtained from the hypothesis test data using Will Coxon before and after the treatment of coloring pictures is $0,000(0.05)$, it means that there is an effect of coloring pictures on fine motor development in children aged 4-5 years. As the physical development of children aged 4-5 years, the child's motor development can be coordinated. Each activity is aligned with their needs or interests. At this time marked by excess movement or motor skills that are very agile, therefore, this age is an ideal time to learn skills related to fine motor development, namely by drawing, painting and typing [3].

The factors that influence fine motor development include the development of the nervous system, physical abilities that make it possible to move, children's desire to motivate to move, supportive environment, aspects of the child's psychology, age, sex, genetic and chromosomal abnormalities [8].

The results of this study are in line with research conducted by Aprilena [9]. Based on the results of research that by using drawing media with various crayons can improve fine motor skills in children. Based on the research results obtained by the first cycle with an average value of $31 \%$ and in the second cycle increased to $91 \%$ results $\mathrm{p}$ value $=0.001$.

\section{CONCLUSION}

It is known that fine motor development before being given coloring treatment pictures of respondents there are $50 \%$ of respondents in the undeveloped category with a mean value of 1.87 and the standard deviation value is 0.937

Knowing fine motor development after being given a coloring treatment picture of the respondents there are 50\% of respondents in the category of developing according to expectations with a mean value of 2.90 and the standard deviation value is 0.712

There is an effect of coloring pictures on fine motor development in children aged 4-5 years group A in AlMunawar Kindergarten, Nanggung District, Bogor Regency in 2018 , with a $\mathrm{p}$ value of $0.00(<0.05)$.

\section{REFERENSI}

[1] Nurihsan, Juntika. 2007. Perkembangan Peserta Didik. Bandung : Sekolah Pasca Sanjana UPI.

[2] Balibankes, Depkes. 2013 Riset Kesehatan Dasar. 2013. Jakarta : Badan Penelitian dan Pengembangan Kesehatan Kementrian Kesehatan Republik Indonesia. 
[3] Aisyah, Siti. 2010. Perkembangan dan Konsep Dasar Pengembangan Anak Usia Dini. Jakarta : Universitas Terbuka.

[4] Widiaty, Tri. 2012. Meningkatkan Kemampuan Motorik Halus Anak melalui Metode Melipat Kertas pada Anak Kelompok B TK ABA Gani Socokangsi JatinomKlaren Tahun Ajaran 2011/2012. Surakarta : Universitas Muhammadiyah Surakarta. (Skripsi)

[5] Mar'at, Samsunuwiyati. 2013. Psikologi Perkembangan. Bandung : PT Remaja Rosda karya.

[6] Martini, Jamaris. 2006. Perkembangan dan Pengembangan Anak Usia Taman Kanak-Kanak. Jakarta : Grasindo.

[7] Murdian, Niluh. 2015. Pengaruh Kegiatan Mewarnai gambar dalam meningkatkan perkembangan motorik halus anak di kelompok B TK Jaya Kumara Desa Balinggi Kecamatan Balinggi Kabupaten Parigi. Yogyakarta : Universitas Negeri Yogyakarta. (Skripsi)

[8] Hurlock, Elizabeth B. 2013. Perkembangan Anak. Penerjemah : Meitasari Tjandra dan Muslichat Zarkasih. Jakarta : Erlangga.

[9] Aprilena. 2014. Meningkatkan Kemampuan Motorik Halus Pada Anak Melalui Kegiatan Menggambar Dengan Menggunakan Anek Warna Ktayon Pada Kelompok B2 TK IPKB Curup Timur. Surakarta : Universitas Muhammadiyah Surakarta. 